\title{
Correction to: The Holship ruling of the ECtHR and the protection of fundamental rights in Europe
}

\author{
Hans Petter Graver ${ }^{1}$
}

Published online: 7 March 2022

(c) @ ERA 2022

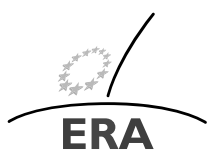

EUROPÄISCHE RECHTSAKADEMIE ACADEMY OF EUROPEAN LAW ACADEMY OF LUROPEAN LAW ACADEMIE DE DROIT EUROPEEN ACCADEMIA DI DIRITTO EUROH

\section{Correction to: ERA Forum https://doi.org/10.1007/s12027-022-00701-0}

The previous version of the article did not state that the author, Professor Hans Petter Graver, acted as a counsel for the Norwegian Confederation of Trade Unions and the Norwegian Transport Workers' Union in the case before the European Court of Human Rights presented in his article.

This possible conflict of Interest has now been added to the original publication.

Open Access This article is licensed under a Creative Commons Attribution 4.0 International License, which permits use, sharing, adaptation, distribution and reproduction in any medium or format, as long as you give appropriate credit to the original author(s) and the source, provide a link to the Creative Commons licence, and indicate if changes were made. The images or other third party material in this article are included in the article's Creative Commons licence, unless indicated otherwise in a credit line to the material. If material is not included in the article's Creative Commons licence and your intended use is not permitted by statutory regulation or exceeds the permitted use, you will need to obtain permission directly from the copyright holder. To view a copy of this licence, visit http://creativecommons.org/licenses/by/ $4.0 \%$.

Publisher's Note Springer Nature remains neutral with regard to jurisdictional claims in published maps and institutional affiliations.

The original article can be found online at https://doi.org/10.1007/s12027-022-00701-0

H.P. Graver

h.p.graver@jus.uio.no

1 University of Oslo, Oslo, Norway 